\title{
New Greek migrant (dis)identifications in social media: Evidence from a discourse-centred online ethnographic study
}

\author{
Mariza Georgalou ${ }^{1 凶}$
}

Since the eruption of the Greek crisis in 2010, thousands of highly educated and skilled Greeks have chosen or have been forced to migrate abroad in pursuit of better career prospects and living standards. This recent migratory wave has been termed 'new' Greek migration (Panagiotopoulou et al., 2019). Considering the transformative impact of social media on the lives and experiences of migrants as well as the pivotal role of social media in (dis)identification and identity construction processes, this paper aims at exploring the ways in which new Greek migrants construct their identities in their social media discourse. Based on a synergy between the constructionist approach to identity, discourse studies, and online ethnography, the paper presents and discusses empirical data (social media content and interviews) from five selected new Greek migrants settled in the UK and Germany, who write about and capture their migration experiences on their blogs, Facebook, Twitter, and Instagram accounts. As shown in the analysis, new Greek migrant identities are hybrid and multifaceted, constructed and negotiated through a gamut of discursive means, including stance-taking, intertextuality, entextualization, and coupling. Having the migrants' own voice and perspective at the heart of the analysis brings to the forefront significant socio-cultural dimensions of new Greek migration, often downplayed in economic and political analyses of the phenomenon. In this fashion, the potential of social media to heighten awareness of new Greek migrants' (dis)identification processes is verified.

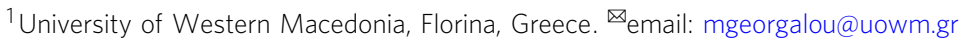




\section{Introduction}

$\mathrm{t}$ is by now a truism that the advent of social media has radically transformed the lives and experiences of migrants worldwide. Social media platforms are used by migrants to access information, resources, and news in relation to their home and host countries as well as for purposes of communication, emotion-management, intercultural relations, identification, participation, political protest, and sending/receiving remittances (Leurs and Prabhakar, 2018, p. 247, see also a review of studies in Georgalou, 2019, pp. 138-139). Contemporary migrants, thus, are digitally 'connected migrants' (Diminescu, 2008), who benefit from social media opportunities to be here and there at the same time and to co-ordinate and organize their lives.

Bringing into dialogue insights provided by the social constructionist approach to identity, discourse ${ }^{1}$ studies and online ethnography, this paper discusses how new Greek migrants discursively construct their identities while participating in social media. Two key arguments have motivated and given direction to my discussion. First, migrant identities are special (De Fina, 2003; Krzyżanowski and Wodak, 2007). On the one hand, migration entails an endless search for belonging as well as an endeavour to face constantly shifting requirements for social acceptance and recognition (Krzyżanowski and Wodak, 2007, pp. 98-99). Hence, migrant identities are 'inherently ambivalent and constantly subject to inherent and continuous change' (Krzyżanowski and Wodak, 2007, p. 115). On the other hand, despite the fact that migration is often viewed as something undertaken by collectives (as denoted by the terms 'diasporas', 'migrant groups' or 'ethnic minorities'), recent scholarship puts forward that migration constitutes a subjective and unique experience that defies generalization (De Fina, 2003, pp. 3-4; Krzyżanowski and Wodak, 2007, p. 99).

Second, social media have been found to be significant outlets for identity construction and asserting or eschewing belonging (see Page, 2012, articles in Seargeant and Tagg, 2014; Georgalou, 2017, articles in Leppänen, Westinen et al., 2017). Along the lines proposed by Leppänen, Kytölä et al. (2017, pp. 8-9), social media are defined here broadly as online platforms which, via the internet and the use of digital devices such as computers and smartphones, promote social interaction between participants, either synchronously or asynchronously, publicly or privately, through the sharing and exchange of discourse material (e.g. text, pictures, videos, hyperlinks or other semiotic resources). On the basis of this broad definition, social media may include blogs, microblogging sites such as Twitter, social network sites such as Facebook, media-sharing sites such as YouTube and Instagram, consumer review sites such as TripAdvisor, wikis, podcasts, discussion forums, instant messaging and VoIP apps such as Skype and Viber, chatrooms, and virtual worlds such as World of Warcraft (Leppänen, Kytölä et al., 2017, pp. 8-9; Seargeant and Tagg, 2014, pp. 3-4). Regarding digital migration in particular, as Leurs' (2015) seminal work has established, migrants appropriate social media to articulate identity alignments as well as to reimagine their migratory roots by producing, circulating, and viewing representations of transnational belonging.

To date, nuanced qualitative research on new Greek migrants is scarce not only within discourse studies but also in other fields. Although several studies have examined the sociological and economic aspects of new Greek migration (see Labrianidis and Pratsinakis, 2016; Bartolini et al., 2017, articles in Panagiotopoulou et al., 2019), questions related to self- and otherperception and self- and other-presentation remain largely unexplored. My work aims to address the dearth of research in this area, drawing on ethnographic data (social media content and interviews) from selected new Greek migrants settled in the
UK and Germany, two of the most preferred destination countries among new Greek migrants (New Diaspora, 2016).

The paper is organized as follows. First, I delineate why new Greek migrants make a special and important case to study. This is followed by a description of the theoretical framework I adopted for the study of new Greek migrant identities as well as my discourse-analytical orientations. Next, I provide an account of discourse-centred online ethnography, upon which my research design was based. I then move on to the main part of the article, in which I present and analyze social media data and interview excerpts from five new Greek migrants. Lastly, I close with the conclusions and implications of my study.

\section{New Greek migration}

Migration is not a new phenomenon for Greece. In modern Greek migration history, two migration waves can be identified: the first one occurred after the formation of the Greek state in the late 19th-early 20th century, followed by a second one after World War II. Between the 1950s and 1970s, many Greeks migrated to Western Europe (mainly West Germany), the United States, Canada and Australia. In the 1990s, Greece turned from a country of migration into a migrant-receiving country of people from the Balkans and the former Soviet Union. From 2010 onwards, Greece has once more become a country of migration because of the economic crisis. This recent migration wave, which has acquired a massive character, ${ }^{2}$ has been termed 'new' Greek migration (Panagiotopoulou et al., 2019).

But what exactly is 'new' about the new migration from Greece? First, the main feature of this new migration phase is that it has been propelled by the advancing processes of globalization and intra-European mobility as well as the crisis in Greece (Siouti, 2019). Second, compared to Greek migrants of the previous waves, new Greek migrants have remarkably diverse socioeconomic backgrounds. The 1960s-1970s migration comprised of people almost uniformly unskilled and of lower education, who left Greece to be employed as workers in the thriving industries of Western Europe (Pratsinakis, 2019a). In sharp contrast, new Greek migrants are highly educated and skilled (Bartolini et al., 2017). ${ }^{3}$ Moreover, they grew up in the era of modern technology which has diminished geographical distance, facilitating transnational activity (Aravossitas and Sugiman, 2019).

Since the onset of the Greek crisis, thousands of highly educated and skilled Greeks have chosen or have been forced to migrate abroad (for the distinction between choice and necessity, see Pratsinakis, 2019b, Pratsinakis et al., 2020), driven by monetary as well as non-monetary factors (Bartolini et al., 2017). Rising unemployment, cuts in salaries and allowances, and heavy taxation are cited as strong monetary drivers (Pratsinakis et al., 2017). From a non-monetary perspective, a substantial majority has migrated due to feelings of lacking any prospects in Greece and due to feelings of disappointment with the political establishment of the country and its state institutions (Labrianidis and Pratsinakis, 2016). Along with the aforementioned, a number of socio-psychological motivations for migration have been reported, such as perceptions of the erosion of civil, cultural, social, and human rights, lack of meritocracy, poor working conditions and lack of decent work, and the perception that individuals are not valued for their contribution to work and society (Groutsis et al., 2019). Greek skilled migrants have also been driven by personal aspirations for upward professional mobility and intellectual achievement; for building a better life abroad and securing a better future for their children; and for trying a new experience in general (Labrianidis and Pratsinakis, 2016; Bartolini et al., 2017). 
Having presented the social and historical context in which new Greek migration emerged, I proceed to a discussion of my theoretical and analytical underpinnings.

\section{Theoretical and analytical orientations}

This paper adopts a social constructionist approach to identity, according to which identity is dynamic, flexible, and necessarily contextual-socially, politically, culturally, and discursively (Benwell and Stokoe, 2006). Driven by Leppänen, Kytölä et al.'s (2017) work on social media and identity, I draw on Brubaker and Cooper's (2000) multidimensional framework on the ways in which social actors engage in identity work. They suggest three clusters of terms: (1) identification, (2) self-understanding and social location, and (3) commonality, connectedness, and groupness.

Identification is concerned with acts in which we need to identify ourselves, that is, to characterize ourselves, to locate ourselves vis-à-vis others, to situate ourselves in a narrative, and to place ourselves in a category (or categories) in different contexts (Brubaker and Cooper, 2000, p. 14). Identification can be either relational or categorical (Brubaker and Cooper, 2000, p. 15). This means that we may identify ourselves (or others) with respect to different types of relationships (e.g. kinship, friendship, professional or institutional relationships). We may also identify ourselves (or another person) in terms of membership in a class of persons sharing certain categorical attributes (e.g. race, ethnicity, language, nationality, citizenship, gender, sexual orientation). It should be stressed that identification is not solely about pursuing and showing affinity, but it can also involve various acts of disidentification whereby we can disengage or distance ourselves from certain identificational stances or possibilities (Leppänen, Kytölä et al., 2017, p. 15). Moreover, Brubaker and Cooper distinguish between self-identification and the identification of ourselves by other social actors (e.g. family and friends) as well as by powerful, authoritative institutions (e.g. the state, school, media, even socio-cultural discourses, and public narratives) (Leppänen, Kytölä et al., 2017, p. 15). Another component of identification, presented in brief by Brubaker and Cooper (2000, p. 17), pertains to the psychodynamic meaning attached to our emotional identification with another person, category, or collectivity.

The second cluster of identity terms in Brubaker and Cooper's framework is self-understanding and social location, or 'situated subjectivity', which refers to our practical cognitive and affective sense of who we are, of our social location and of how, on the basis of the first two, we are prepared to act (2000, p. 17). This sense of the self and its location concerns particular beliefs, norms, rights, obligations, and behaviours, as conceived by people in a given social situation (Leppänen, Kytölä et al., 2017, p. 16).

The third key area in Brubaker and Cooper's identity theorization is comprised of the cluster of commonality, connectedness, and groupness, which has to do with collective identities (2000, p. 20). Commonality relates to the sharing of some common attribute(s), while connectedness refers to the relational ties that link people. As they highlight, "[n]either commonality nor connectedness alone engenders "groupness"-the sense of belonging to a distinctive, bounded, solidary group' (Brubaker and Cooper, 2000 , p. 20). Groupness depends partly on the degrees and forms of commonality and connectedness, yet it can also depend on other factors such as 'particular events, their encoding in compelling public narratives, prevailing discursive frames, and so on' (Brubaker and Cooper, 2000).

As maintained by Leppänen, Kytölä et al. (2017, pp. 19-20), Brubaker and Cooper's identity framework is especially useful for the study of communication in social media for two reasons. First, it enables the analyst to conceptualize and explore social media as realms where identity work is a key issue. More specifically, it helps them understand and explain how, irrespective of geographical distances and/or asynchronicity of communication, social media users can meaningfully present themselves and interact with other, known and unknown, users. Furthermore, it allows the analyst to comprehend the processes and practices via which social media users can participate in and maintain digital communal spaces, be that loose or close-knit communities. Second, the fact that this model conceptualizes identity as something that social actors actively pursue adds weight to 'the processes and practices of communication and representation, and, hence, of their investigation with specific reference to the means with which identifications are constructed, negotiated and made sense of (Leppänen, Kytölä et al., 2017, p. 20).

In the data under scrutiny (see next section), the means with which the selected participants' (dis)identifications were 'constructed, negotiated and made sense of, to borrow Leppänen, Kytölä et al.'s (2017, p. 20) phrasing, were the following:

- Stance-taking: The term deals with the expression, whether by overt assertion or by inference, of a writer's or speaker's personal attitudes, feelings, beliefs, evaluations, judgements, or commitment towards a precise target (Biber and Finegan, 1989; Du Bois, 2007). This target can be an interlocutor, a person represented in the discourse, ideas represented in the discourse, or other texts (Kiesling, 2011). Stance is distinguished into affective (how we express our emotional states) and epistemic stance (how we convey our certainties and knowledge) (Jaffe, 2009, p. 7). A central notion pertinent to stance-taking is that of alignment or disalignment (Du Bois, 2007), namely, our lining up or not lining up with others' attitudinal assessments, beliefs, and assumptions. A stance is always an act of self-presentation and social judgement via which we express something not only about ourselves but also about others (as being or not being like us).

- Intertextuality: The notion of intertextuality, developed by theorists such as Bakhtin (1981), Kristeva (1986), and Fairclough (1992), refers to the traces one text bears of preceding texts, for example, by means of alluding, quoting, echoing, paraphrasing or linking. In this paper, I am specifically looking at discourse representation, that is to say, the incorporation of other parts of texts into a text, which is usually marked as such, with devices such as quotation marks and reporting clauses (e.g. 'they said that...') (Fairclough, 1992, p. 105, 107). Another category of intertextual references I am also discussing is allusions to popular culture texts, such as television shows and theatrical plays. As will be shown in the analysis, intertextuality is a social process (Jones et al., 2015, p. 7) that enables us to witness how people, by creating linkages between texts, are engaged into active processes of (dis) identification.

- Entextualization: According to Blommaert (2005, p. 47), entextualization 'adds important qualifications and turns intertextuality into an empirical research programme'. The term is concerned with the ways via which the producer of a text (re)uses linguistic and semiotic resources, relocating thus discourse material from one context to another. This process involves decontextualization, namely, extracting discourse material out of its context, and recontextualization of this material, that is, its integration and modification so that it fits in a new context. The outcome of entextualization is a new discourse related to a new context and complemented by a particular metadiscourse which 
offers a sort of 'preferred reading' for the new discourse (Blommaert, 2005). As Leppänen et al. (2014, p. 115) observe, entextualization constitutes a process of cardinal importance for the construction of identities in social media as well as a useful concept for comprehending the complex discourse practices that take place in social media broadly.

- Coupling: The concept of coupling, introduced by Martin (2000) and taken up by Zhao (2011) and Zappavigna (2012, 2018), is used to describe textual relations. Coupling can occur between metafunctional variables (e.g. ideational and interpersonal), ${ }^{4}$ between different semiotic resources (e.g. words and image) and across strata (e.g. semantics and phonology) (Zhao, 2011, p. 144). Herein, I focus on couplings of social media written verbiage and image as well as other affordances, such as hashtags, in order to demonstrate how these textual relations can realize certain (dis)identifications.

In the following section, I account for my methodological approach and data collection.

\section{Methods, data, and participants}

In the context of the project "Greek youth in crisis: Representations of skilled immigration in social media and pop culture", the research team of the University of Western Macedonia, Greece, conducted a 16-month study (April 2018-August 2019) on new Greek migration, having a two-pronged aim. ${ }^{5}$ First, it explored the ways in which new Greek migrants construct their identities and position themselves in relation to their migration while participating in social media platforms, including blogs, Facebook, Twitter, and Instagram. Second, it examined how new Greek migration is discussed and constructed in Greek popular culture discourse, particularly in advertisements, TV series, and lifestyle press (for some of the project's key findings, see Georgalou et al., 2019).

Anchored to the first aim of the project's study, in this paper I present empirical evidence on the identity construction of selected new Greek migrants on social media. Methodologically, I draw on the discourse-centred online ethnographic paradigm (Androutsopoulos, 2008, 2013), which combines online ethnography with discourse analysis. This approach takes two dimensions: a screen-based and a participant-based one. The former concentrates on systematic, longitudinal, and repeated observation of online discourse, while the latter draws upon direct engagement with online actors, namely the producers of this online discourse, via face-to-face and/or mediated interviewing (e.g. using email, instant messaging services or Skype).

My informants, four new Greek migrants in the UK and three in Germany, were recruited via purposive sampling abiding by certain criteria. More specifically, they should: be 25-35-year-old Greeks at the time they left Greece; hold a BA and an MA or MSc degree; have left Greece from 2010 onwards; have settled in either the UK or Germany; be social media savvy; and have settled in the host country for at least one year looking for a job or already working there. The informants were invited to participate via an email message. A full participant information and consent protocol were administered to them prior to the commencement of all research. Once they agreed to participate, I started my systematic observation of their social media discourse and, subsequently, based on this observation, I carried out in-depth semistructured interviews with them via Skype. The interviews lasted about one hour each and were conducted in Greek. As part of the screen-based dimension of the study, I collected from these participants profile information, posts and status updates, comments (written by them and their social media audience), video and article links as well as photographs from their blogs, Facebook, Twitter, and Instagram accounts. These are the social media platforms the participants stated they have been using when asked in my initial contact with them. The aforementioned data were either publicly or semi-publicly available. In the cases of Facebook and Instagram, as most of the accounts were private, I had to send requests to the participants in order to have access to their posts. Examining their private communication on social media (e.g. direct messages to third parties on Twitter or Instagram, or exchanges via Facebook Messenger) would involve complex ethical considerations, and therefore it did not constitute part of my research. As far as the participant-based dimension of the study is concerned, my dataset also includes extracts from the Skype interviews, messages from my email and Facebook Messenger communication with the informants, and field notes from my observation of their social media activities. The data cover the period just before the migration of each participant until August 2019.

Herein, I present data from three new Greek migrants in the UK, Dimitris, Antonia, and Thalia, and two new Greek migrants in Germany, Rigas, and Chrysoula. ${ }^{6}$ Table 1 shows an overview of the participants' background: the year of their birth, their city of origin in Greece, the place and time of their settlement in the host country, their studies, their occupation in the host country and the social media platforms they use.

Having provided some essential information about my research methods and data, I now turn to the analysis proper. Adapting Brubaker and Cooper's (2000) apt identity framework to the data, the analysis revolves around the ways in which new Greek migrants' identities are discursively constructed in social media and the interviews through the processes of self- and otheridentification, disidentification, and seeking or eschewing commonality, connectedness, and groupness.

\section{Analysis}

Self-identifications. I start with the process of self-identification, namely, how the selected participants characterize and situate themselves. The following identity categories were discerned: the economic migrant, the nostalgic migrant, the lifestyle migrant and the transnational migrant.

Economic migrant. In his tweet, included in Fig. 1, Dimitris assigns himself the evaluative attribute of the 'economic migrant', highlighting the fact that his migration decision was shaped by necessity ('I was forced'). Concurring with Pratsinakis et al. (2017), necessity here should not be viewed only in terms of sheer economic need, but also in terms of a broader context of lack of prospects in Greece.

Nostalgic migrant. Figure 2 is a screenshot from Rigas' blog, where we observe that he identifies himself as an emigrant in the

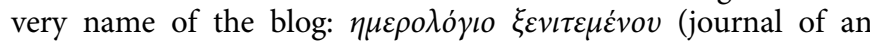
emigrant). The Greek term for 'emigrant', ' $\varepsilon \varepsilon v i \tau \mu \varepsilon \dot{v} \nu \varsigma^{\prime}$ (xeniteménos), is an instance of affective stance, which signals Rigas' specific feelings. In his review of Greece's long migration history (see the section "New Greek migration") and its strong and continuing imprint on the country's culture, Pratsinakis (2019b, p. 14; see also references therein) points out that:

The experience of absence from one's homeland is culturally elaborated in Greek under the concept xenitiá, literally meaning exile. This concept describes an emotional state which revolves around poignant feelings of nostalgia and loss and as such is associated both with those who stay and those who leave. It is a state of longing for the sojourners, particularly those whose absence is not entirely 


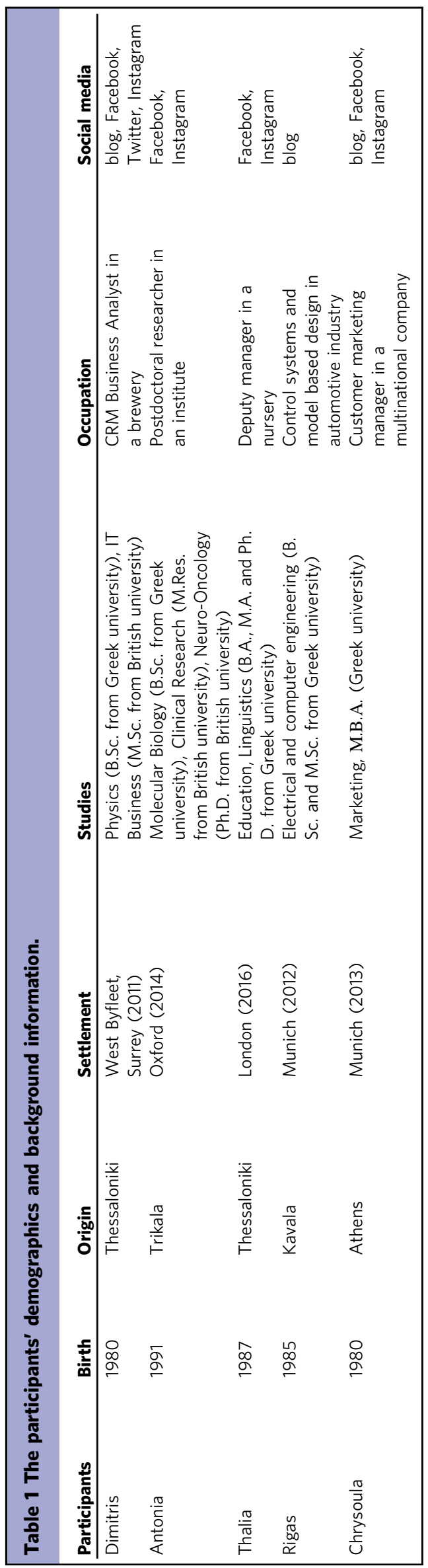

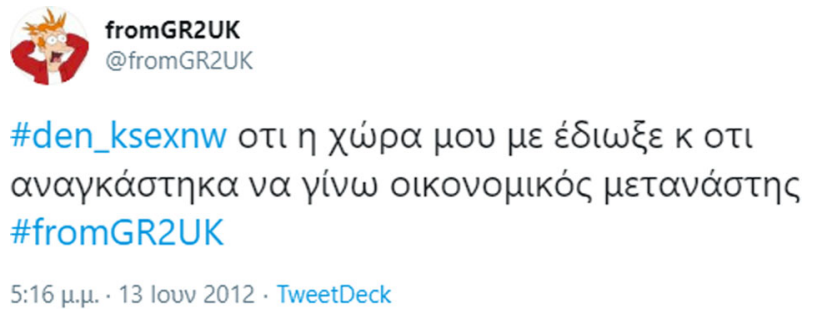

Fig. 1 Self-identification as an economic migrant on Twitter. Translation: \#idon't_forget that my country kicked me out and I was forced to become an economic migrant \#fromGR2UK.

voluntary, by those who stay, and a condition of estrangement by those who leave related to feelings of discrimination and a longing for home.

Rigas' nostalgia for Greece is also reinforced visually by means of the blog's interface, where the drawings of the olive branch, the ship on the sea, the church, and the sun (as visual metonymies for Greece's distinctive flora, maritime tradition, coastline, Orthodox Christianity and weather, respectively) function as strong cultural indexes of Greekness. ${ }^{7}$

Lifestyle migrant. As previously stated (see the section "New Greek migration"), new Greek migration amalgamates economic migration with migration for a better quality of life, what Benson (2011) terms 'lifestyle migration'. More often than not, my informants construct their migrant identities without spelling them out, as were the cases of 'economic migrant' and 'xeniteménos' above. Instead, they allow them to be 'given off (Goffman, 1956) through the semiotic means they employ. The identity of the lifestyle migrant is mainly witnessed on Instagram, chiming thus with the platform's general lifestyle aesthetic (Leaver et al., 2020). By way of illustration, Chrysoula shares an image, taken by her husband, which depicts her together with her sons in one of Munich's parks enjoying a Sunday walk (Fig. 3). ${ }^{8}$ On the other hand, Dimitris posts a 'still life self-image' (Zappavigna and Zhao, 2020), where the beers and the snacks represent dimensions of his own experience (in this case, having a good time in a London pub) (Fig. 4). In both instances, the participants communicate a perspective that could be glossed as 'see how I spend my spare time while abroad'. In this fashion, they construct the 'discourse of the good life' (Aguirre and Graham Davies, 2015) in the host country, which although not directly asserted, it appears to be visually, and hence forcefully, presupposed.

Transnational migrant. Through systematic observations across their social media posts, my participants have been found to portray themselves with affiliations to two cultural communities: the Greek community and the host one. Two examples, extracted from Chrysoula's blog apomamasema (from mother to mother), will be used to illustrate this point.

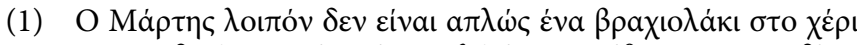

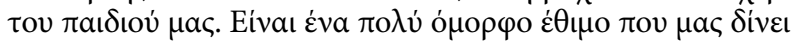

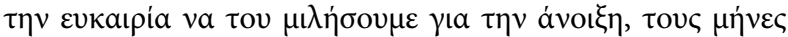

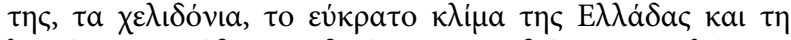

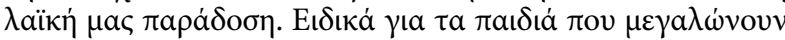

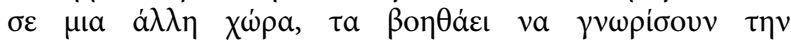

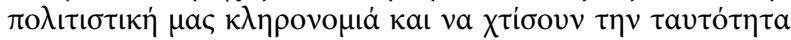

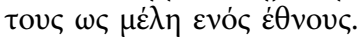

'So the March bracelet is not just a small bracelet on our kid's wrist. It is a very beautiful custom that gives us the opportunity to talk to them about spring, its months, the 


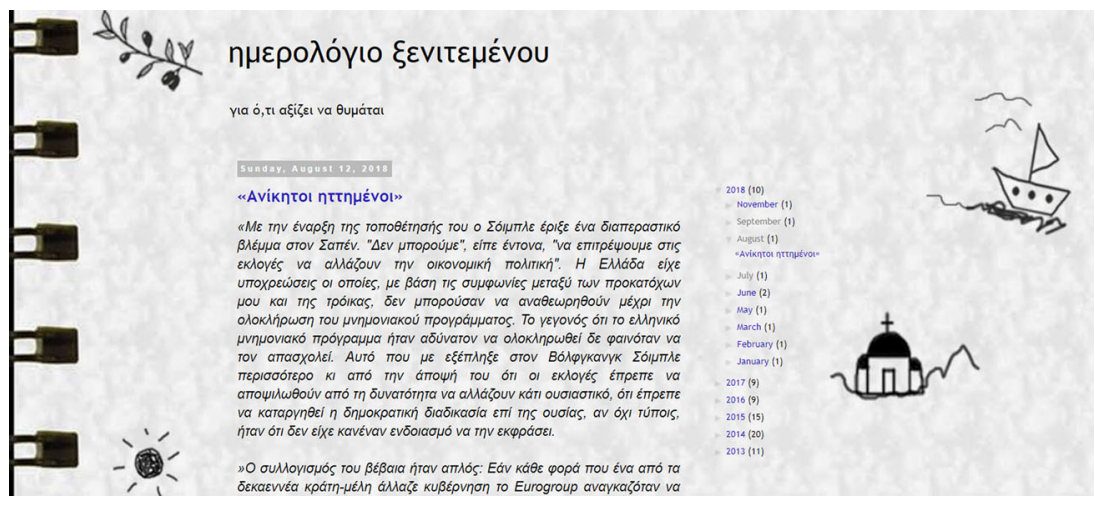

Fig. 2 Constructing a nostalgic migrant identity. Screenshot from Rigas' blog journal of an emigrant.

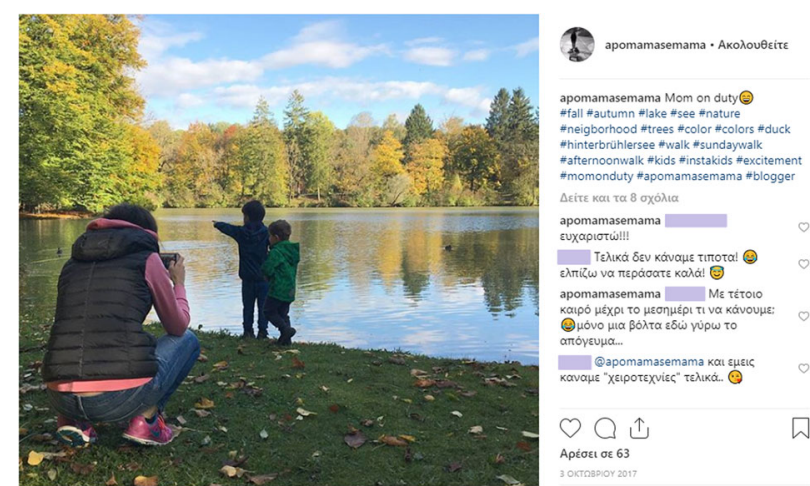

Fig. 3 Constructing a lifestyle migrant identity on Instagram. Constructing a lifestyle migrant identity on Instagram. Screenshot from Chrysoula's Instagram account.

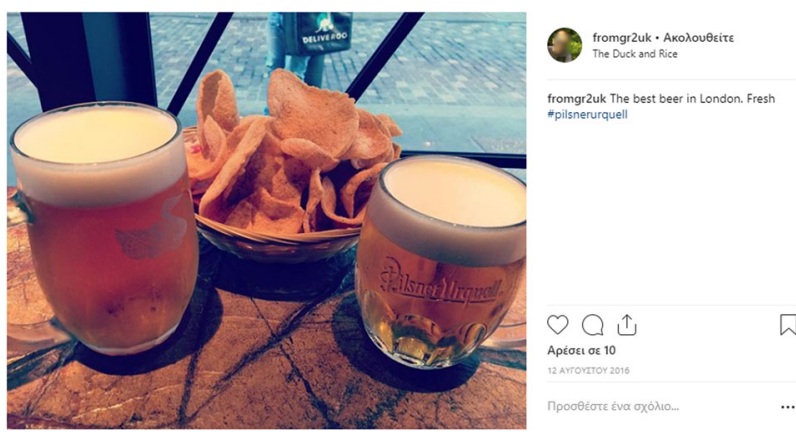

Fig. 4 Constructing a lifestyle migrant identity on Instagram. Screenshot from Dimitris' Instagram account.

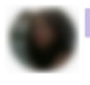

19 February 2016

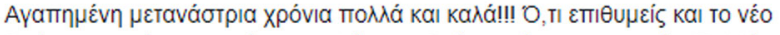

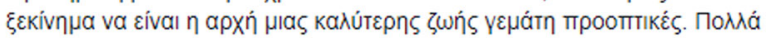

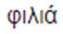

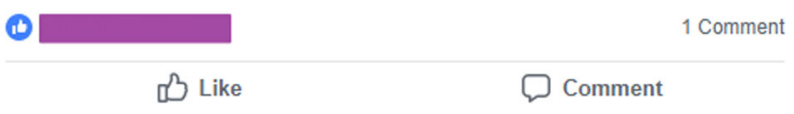

Fig. 5 Birthday wish on Thalia's Facebook Wall. Translation: Beloved migrant many happy returns!!! May all your wishes come true and the new beginning will be one of a better life full of prospects. Many kisses.

swallows, Greece's temperate climate and our folk tradition. Especially for kids who are growing up in another country, it helps them to become acquainted with our cultural heritage and build their identities as members of a nation.' (apomamasemama blog, 4 March 2016).

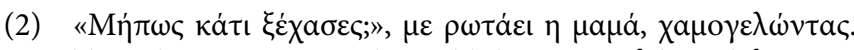

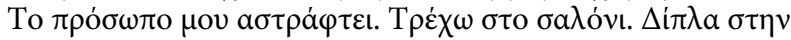

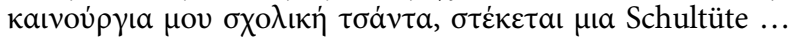

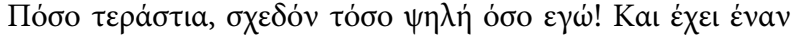

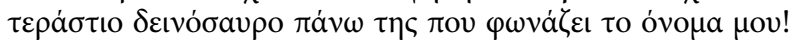

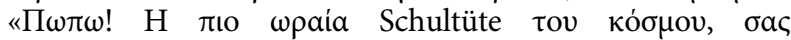
$\varepsilon v \chi \alpha \rho ı \tau \dot{\omega} ! »$. Tovৎ $\alpha \gamma \kappa \alpha \lambda ı \dot{\zeta} \zeta \omega$.

"'Have you forgotten something?", asks mom, smiling. My face is lit up. I run towards the living room. Next to my new school bag, there is a Schultüte ...How huge, almost as tall as me! It has a huge dinosaur imprinted, who calls my name! "Wow! The most beautiful Schultüte in the world, thank you!” I hug my parents.' (apomamasemama blog, 16 September 2018).

In example 1, Chrysoula refers to the Greek custom of wearing a red and white string bracelet in March, which is supposed to protect children from the spring sun. Here, she constructs a collective Greek cultural identity via the inclusive 'we' ('our folk tradition', 'our cultural heritage'). Notably, Chrysoula attaches much significance to preserving these Greek customs while being in Munich for the children's identity ('Especially for kids who are growing up in another country, it helps them to become acquainted with our cultural heritage and build their identities as members of a nation'). Example 2, on the other hand, is concerned with Schultüte, a German cultural practice according to which the parents give their child on the first day of starting primary school a bag filled with chocolate, candies, toys, and school supplies. In this case, Chrysoula makes use of a constructed dialogue (Tannen, 2007), whereby by impersonating her son in first-person narration, she attempts to bestow authenticity and immediacy to the description. In doing so, she employs positive affective stance-taking in relation to the embracement of this custom ('smiling', 'My face is lit up', 'Wow!', 'thank you', 'I hug'). By examining these two instances in parallel, we observe that Chrysoula projects a transnational identity (Vertovec, 2004): on the one hand, she claims Greekness and, on the other, she legitimizes herself and her family as German citizens, advancing, thus, an interwoven relationship between the home and the host society.

Other-identifications. For my participants, a great deal of identity work is done by others, not just by themselves. In this subsection, I look at how they are identified by specific social actors, namely, close friends and unknown members from their social media audience, as well as by publicly circulated discourses.

By friends. As Stæhr (2015) and Georgalou (2017) have suggested, birthday posts on Facebook are a good place to look for 


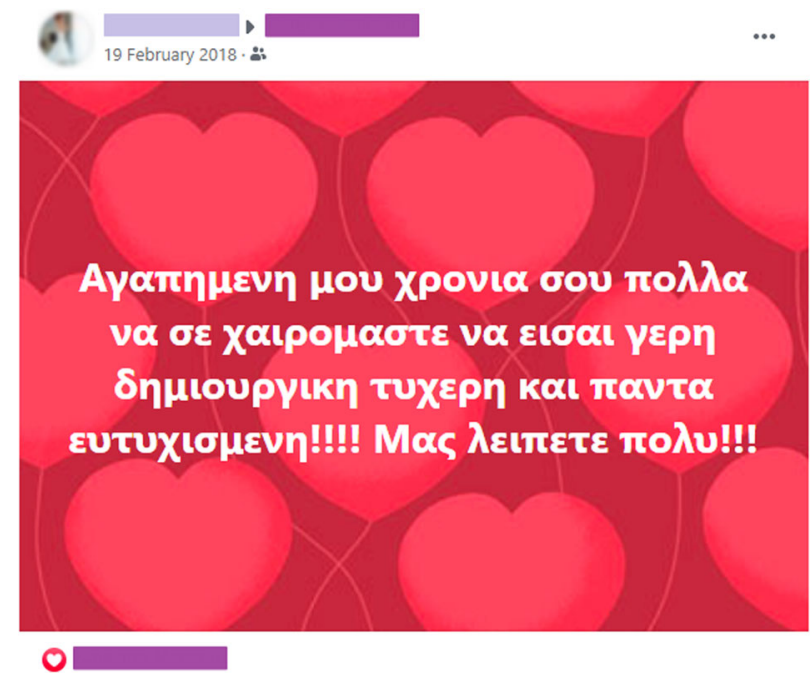

Fig. 6 Birthday wish on Thalia's Facebook Wall II. Translation: My beloved, happy birthday, wishing you to be healthy, creative, lucky, and always happy!!!! We miss you a lot!!!.

identity other-constructions and other-identification practices. Figures 5 and 6 present two birthday wishes Thalia has received on Facebook. In the wish shown in Fig. 5, posted approximately one month after Thalia's settlement in London, a friend directly assigns her the endearing label 'beloved migrant'. In this way, the friend highlights Thalia's new identity facet, further enforcing it with the expressions 'new beginning' and 'better life full of prospects'. The post depicted in Fig. 6 was shared on a subsequent birthday celebration, where-along with the wishes-another friend expresses her affective stance towards Thalia and her husband, both verbally ('We miss you' a lot!!!') and visually (by selecting a background with hearts for the text of the post). Although the issue of migration is not explicitly stated, Thalia is constructed, by means of inferencing, as a significant person missing from her friend's life because of migration.

By broader social media audience. Example 3 is a comment written by a female reader of Dimitris' blog fromGR2UK, who takes a powerful affective stance towards his writing, actualized via complimenting.

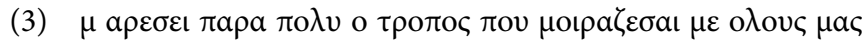

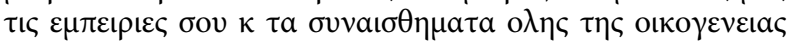
бov. A

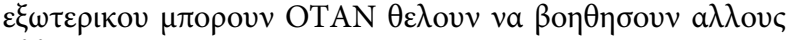

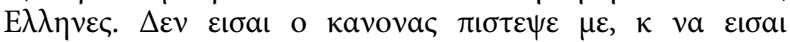

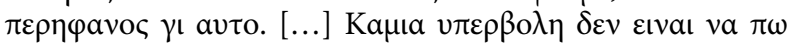

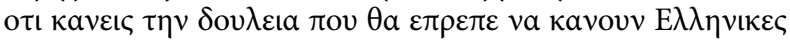

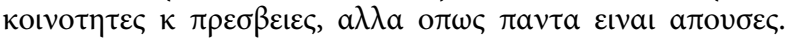
$\sum v v \varepsilon \chi\llcorner\sigma \varepsilon \varepsilon \tau \sigma \mathrm{l}, \chi \alpha \rho a \zeta \varepsilon เ \varsigma, \chi \alpha \mu о \gamma \varepsilon \lambda \alpha \sigma \varepsilon \pi \rho \circ \sigma \omega \pi \alpha \alpha v \theta \rho \omega \pi \omega \nu \kappa$ $\delta ı v \varepsilon\llcorner\varsigma \varepsilon \lambda \pi ı$ $\varepsilon$.

'I like very much the way you share with all of us the experiences and the emotions of your whole family. You're a bright example of the fact that Greeks abroad can help other Greeks WHEN they want. You're not the rule trust me and you should be proud of this. [...] It's not an exaggeration at all to say that you do the job that Greek communities and embassies should do, but as always they are absent. Keep up like this, you make people smile and you give hope.' (comment on the blog from GR2UK, 22 March 2014).
The reader of the blog constructs Dimitris' identity as a skilful storyteller ('I like ... whole family') and as an altruistic migrant ('You're a bright example', 'You're not the rule', 'proud', 'you do the job', 'you make people smile and you give hope'). Moreover, through the wish 'Keep up like this', she creates a community feeling: Dimitris' readers are bonded together thanks to his posts (see also the subsection "Commonality, connectedness, and groupness").

By public discourses. The examples that follow tackle how dominant public discourses identify new Greek migrants. It is worth mentioning that such identifications emerged primarily in my personal email communication with the participants (example 4) and the interviews ${ }^{10}$ (example 5) and not in their social media discourse. I will return to this observation in the concluding section.

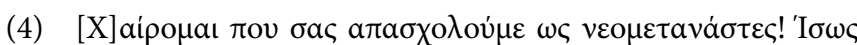

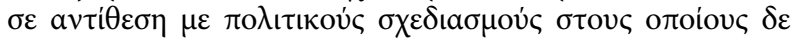

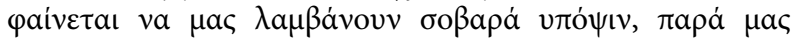

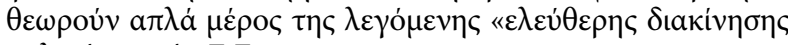

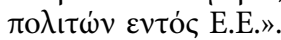

'I'm glad you're interested in us as new migrants! Perhaps in contrast to the policies which do not seem to take us seriously into account considering us just a part of the socalled "free movement of citizens within the EU".' (email communication with Rigas)

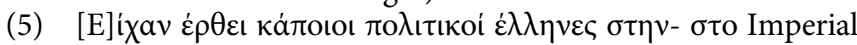

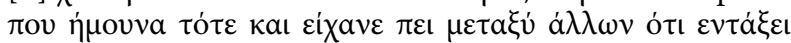

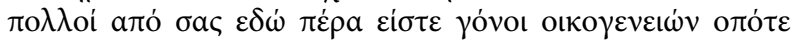

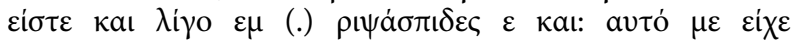

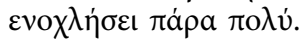

'Some Greek politicians had visited Imperial College, where I was a student then, and they had said, among other things, that many from you here are offspring of wealthy families therefore you are a bit um (.) quitters er and this had bothered me very much.' (Skype interview with Antonia).

Rigas and Antonia employ intertextuality, in the form of reported speech, to refer to certain views put forward by authoritative figures, that is, people who design migration policies in Greece and Greek politicians. In Rigas' case, new Greek migrants' identification is designated by quotation marks ("free movement of citizens within the EU"), which seem to have an ironic function, further enforced by means of evaluation ('just', 'so-called'), whereas Antonia uses indirect speech ('they had said ... that'). In both cases, the intertextual links function as reflections of underlying ideologies (Abell and Myers, 2008, p. 158) purported by public discourses, which represent new Greek migrants as adventurers and cosmopolitans as well as cowards for leaving Greece. Neither do these discourses recognize them as migrants (see also Georgalou, 2019, pp. 153-154), nor do they mention the crisis as a strong incentive to leave Greece. By forging these intertextual links, Rigas and Antonia not only achieve to bring to the fore these views, but also to indicate their disidentification from them through negative affective stancetaking ('do not seem to take us seriously into account', 'this had bothered me very much'; see also next subsection).

Disidentifications. In my data, instances of disidentification were also encountered, dealing mainly with how the informants disidentify themselves from Greece, the host country and discourses about new Greek migration available in the public sphere.

From home country. As already stated, many highly skilled Greek migrants relocated abroad pushed by feelings of disillusionment 
fromGR2UK

@fromGR2UK

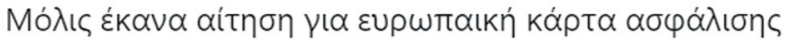

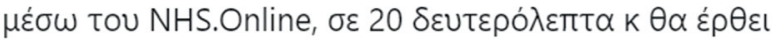
бтítı \#dengyrnaoellada \#1000xroniapiso

Translate Tweet

11:12 pm · 23 Apr 2013 · TweetDeck

Fig. 7 Disidentifying from Greece on Twitter. Translation: I've just applied for a European health insurance card via NHS. Online, in 20 secs, and it'll be sent at home \#idontreturntogreece \#1000yearsback.

from Greece's political system, social organization, and the mentality of some of its people. Figure 7, from Dimitris' Twitter account, offers a brief insight into the disidentification from Greek state institutions.

Dimitris here constructs a relationship of difference (see Stamou, 2018) between the two social welfare systems, the British and the Greek one, as far as their organization and effectiveness are concerned, with the British one being distinctly superior. We witness that Dimitris' detachment from Greece does not occur in the main text of the tweet but in the idiosyncratic hashtags he creates (\#idontreturntogreece, \#1000yearsback), which function as resources of negative affective stance-taking, indicating his disappointment and depreciation towards the Greek system.

From host country. The participants did not only disengage themselves from socio-political maladies and mentalities prevalent in Greece, but also from equivalent ones in the host country. As revealed in their interview accounts, disidentification from the UK was related to Brexit and criminality, whereas disidentification from Germany pertained to the German Chancellery's stance towards Greece during the crisis and the ascent of far-right political parties. Moreover, the overall rise of xenophobia in both countries has constituted a common denominator in the participants' disidentifications. A general flavour can be captured through the following extract:

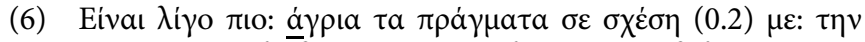

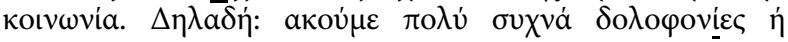

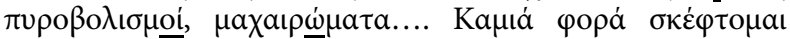

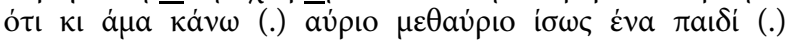

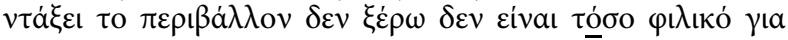

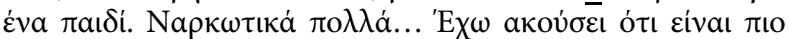

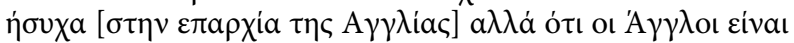

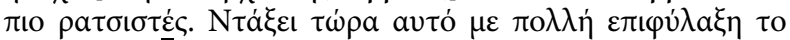

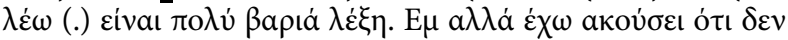

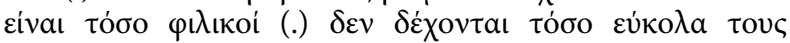

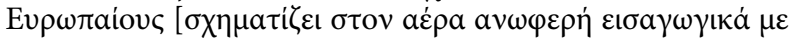

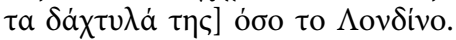

'Things are a bit wilder in relation (0.2) to: the society. That is we very often hear of murders or gunfire, stabbings. ... Sometimes I think that if I perhaps bear a child sooner or later (.) OK I don't know the environment is not that friendly for a child. Many drugs ... I have heard it's more quiet [in the countryside of England] but English people there are more racist. OK now I'm saying this with major reservation (.) it's a very heavy word. Um but I have heard that they are not so friendly (.) they don't accept Europeans [she forms air quotes] that easy as in London.' (Skype interview with Thalia).

As can be seen, Thalia foregrounds the issues of criminality and racism in the UK, which may unsettle a (European) migrant's

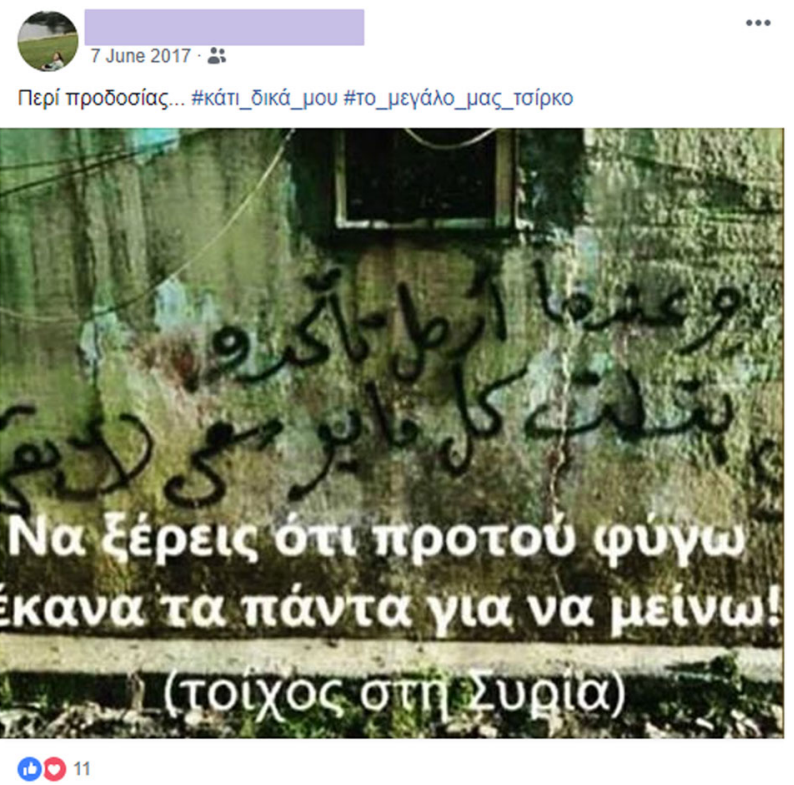

Fig. 8 Disidentifying from public discourses about new Greek migration on Facebook. Translation of opening comment: About betrayal \#my_own_rant \#our_big_circus; translation of the text on the image: You should know that before leaving I did everything to stay! [wall in Syria].

stay and, concomitantly, the creation of a family in the country. However, she does so by dint of epistemic stance-taking characterized by a low level of commitment to the truth she presents ('I don't know', 'with major reservation') and the use of hearsay (Chafe, 1986) evidentials ('we very often hear of, 'I have heard it's more quiet', 'I have heard that they are not so friendly'). Her disidentification, thus, does not derive from personal experience but is based on something that someone else has said. Such care in attribution allows Thalia to undo her statement later, because she was not the one who actually made it (see Myers, 2010, pp. 117-118). At the end of the extract, we notice two remarkable identification processes. First, Thalia aligns herself with the collectivity of Europeans (see also the subsection "Commonality, connectedness and groupness"), ironizing, though, through her air quoting gesture how Europeans are conceptualized by British people. Second, by juxtaposing the English countryside with London ('they don't accept Europeans ... that easy as in London'), she identifies with the latter's multiculturalism and openness. Lastly, Thalia deconstructs the dominant discourse according to which life abroad is heavenly for new Greek migrants (see also Georgalou, 2020), revealing aspects of their migration experience that are not evident, for example, in the migrant lifestyle identifications they project on Instagram (see Figs. 3 and 4).

From public discourses. In this subsection, I am returning to the subject of public discourses on new Greek migration, touched upon in examples 4 and 5. Several instances have been detected in my social media dataset where the participants do not just present how they are identified by these discourses but they go a step further by expressing their disalignment from them (see also Georgalou, 2020, 2021), yet in more implicit ways than in the interviews. A case in point is Fig. 8 from Antonia's Facebook.

In this post, Antonia responds to, and concurrently rejects, a statement made by the Greek actor Kostas Kazakos ${ }^{11}$ in the Greek breakfast TV show Happy Day, on 2 June 2017. ${ }^{12}$ More specifically, the actor said that 'Young people left Greece to work 


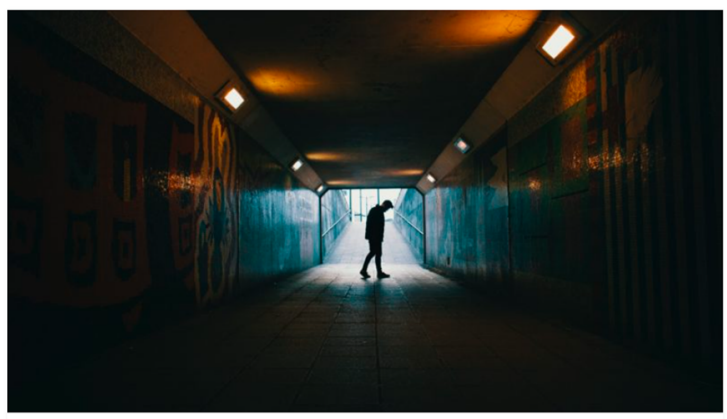

BREXIT

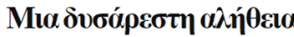

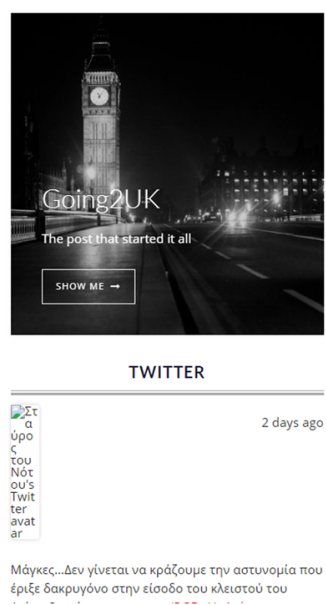

Fig. 9 Connecting with other new Greek migrants. The sections Working in the UK and Living in the UK from Dimitris' blog fromgr2uk.

abroad. And what will be the fate of the country? This is in essence a betrayal.'. Antonia's opening comment presupposes that Kazakos' statement is known (it was extensively discussed in the Greek media resulting in the actor's public repositioning) and therefore, in lieu of referring to it explicitly, she just recycles the

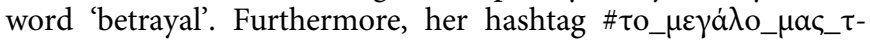
бірко ('our big circus') alludes to a theatrical play, under the same title, directed by and starring Kostas Kazakos. ${ }^{13}$ Yet, anchoring in my knowledge from the interview with Antonia, this hashtag does not aim to pay tribute to the theatrical play, but to present Kazakos' statement as ridiculous, associating it to the negative connotation of circus as a comic spectacle. The hashtag

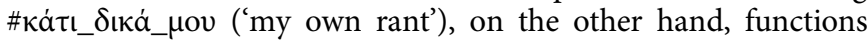
as an index of Antonia's negative affective stance towards the statement. Antonia also entextualizes an image in her post, which although it refers to Syrian refugees, she chooses it so as to adjust it to her own situation (it is as if she says: 'You should know that before leaving Greece I did everything to stay!'). In sum, by creatively coupling the written verbiage (opening comment and hashtags) and the visual elements of the post, Antonia rejects and weakens Kazakos' identification of new Greek migrants as quitters and betrayers. In parallel, and in contradistinction to this identification, she constructs the identity of a migrant who tried to stay in Greece, but in the absence of prospects, she was forced to leave.

Commonality, connectedness and groupness. As Stamou (2018, p. 574) has pointed out, 'the construction of identity acquires meaning in relation to the identities of other people'. Interestingly, in constructing their identities, the participants were found to seek or eschew commonality, connectedness, and groupness with other new Greek migrants. These themes are treated in the instances that follow.

Seeking commonality, connectedness and groupness. In example 7, taken from Facebook, Antonia, through the use of the collective pronoun 'we', invokes commonality and groupness with other new Greek migrants, on the basis of shared social variables (Tagg, 2015 , p. 165): being young, Greeks, scientists, and migrants. It should be noted that, similarly to Dimitris' tweet in Fig. 1, she places the issue of the necessity to migrate to the forefront, albeit in the form of a collective affective stance ("[we] were forced to leave the country'). Moreover, this example corroborates Brubaker and Cooper's (2000, p. 20) argument, who suggested that relational connectedness is not always necessary for groupness; it can stem from a sense of categorical commonality.

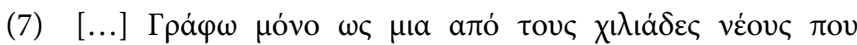

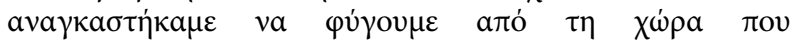

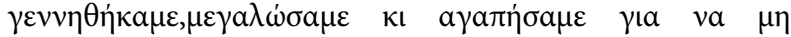

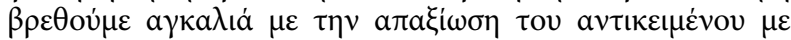

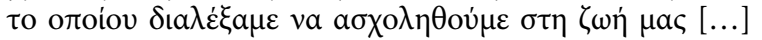

[...] 'I'm just writing as one of the thousands of young people that were forced to leave the country we were born in, grew up and loved so as not to face the disdain of the specialization to which we have chosen to devote our lives' [...] (Facebook, 11 June 2013).

As put by Seargeant and Tagg (2014, p. 9), '[o]n social media, which is predicated on notions of connectedness and the establishment of social networks, these acts of alignment are very much to the fore, and affordances for realizing and displaying connections with others are built into the infrastructure of the applications people use to communicate'. Thus, connectedness and groupness can also be spotted in the ways the participants utilize social media affordances to connect with other new Greek migrants with a view to informing and advising them on issues related to the host country. For example, as shown in Fig. 9, Dimitris has created on his blog two special sections on working in the UK (including the subsections Decision time, $C V$, Cover letter, Networking, and Interview) and living in the UK (including the subsections Life in the UK, Cost of living in the UK, and Food in the UK). ${ }^{14}$ In tandem with the orientation of these sections to connectedness, groupness and alignment, Dimitris is identified as a caring migrant, who is willing to help his migrant compatriots in the UK, drawing on his own personal experience (see also example 3).

Eschewing commonality, connectedness, and groupness. Examples 8 and 9 below will be used to illustrate how Chrysoula and Dimitris differentiate themselves from other new Greek migrants.

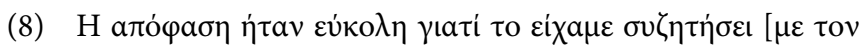

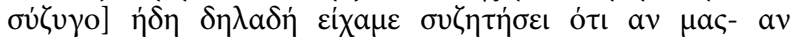

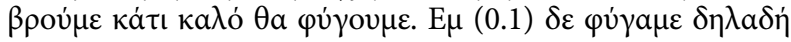




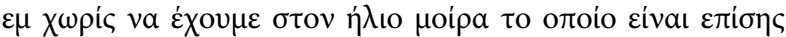

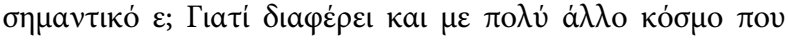

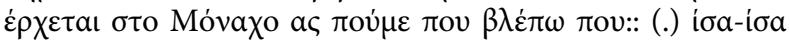

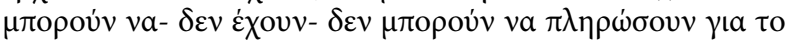

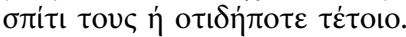

'The decision was easy because we [together with her husband] had already discussed it that is we had discussed that if we find something good we will leave. Um (0.1) that is we didn't leave um without having a place in the sun which is also important right? Because it differs from many other people who come to Munich let's say who as I see they can hardly- they don't have- they can't pay for their home or anything similar.' (Skype interview with Chrysoula).

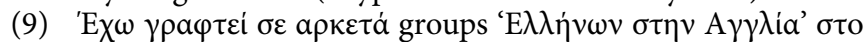
facebook. Kaı a

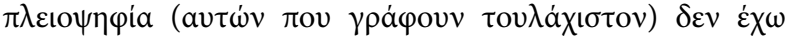

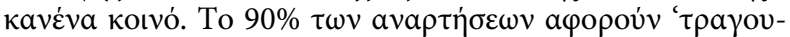

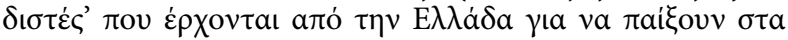

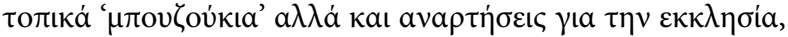

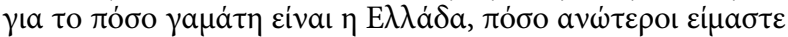
a ó $^{\prime} \lambda$ ouৎ $\kappa \tau \lambda \kappa \tau \lambda$.

'I have joined several groups of "Greeks in England" on Facebook. And I'm wondering why. I feel that in reality with the majority (of those who write there at least) I have nothing in common. $90 \%$ of the posts are concerned with 'singers' who visit from Greece in order to perform at the local 'bouzoukia' ${ }^{15}$ as well as posts about the church, about how much Greece kicks ass, how superior we are from everybody else etc. etc.' (from GR2UK blog, 20 November 2018).

Chrysoula eludes commonality with other Greek migrants in respect of their migration incentives, needs, professional aspirations, and their broader migration experience, suggesting a distinction between skilled/lifestyle vs. unskilled migrants ('if we find something good we will leave', 'we didn't leave um without having a place in the sun', 'they can't pay for their home'; see also note 3 ), realized with the verb "differs". In contrast, Dimitris disassociates himself in a more overt manner, using the phrase 'I have nothing in common', which refers to different cultural practices ('bouzoukia') as well as different cultural values and beliefs (church, 'how much Greece kicks ass', 'how superior we are'). In so doing, Dimitris also points to the different utilizations of social media by Greek migrants: cleaving to Greek habits and emphasizing national uniqueness on Facebook groups vs. advising migrants on seeking employment and acculturating in the UK on his blog (see Fig. 9). One notable aspect that both examples 8 and 9 reveal is that although new Greek migrants share the common attributes of nationality and migration within the crisis era, they do not constitute a homogeneous and cohesive group, unified by the same circumstances of arrival in the host country, the same settlement experiences, the same plans for the future, and the same degree of attachment to the home and host countries.

\section{Concluding remarks}

This paper explored some of the (dis)identifications at play when it comes to new Greek migrants' social media discourse. Being informed by Brubaker and Cooper's multidimensional identity framework and the paradigm of discourse-centred online ethnography, I presented and discussed empirical data from five new Greek migrants, settled in the UK and Germany, who use social media to write about their migration experiences, either in a systematic (in the form of migrant-specific blogs) or in an interspersed manner (amongst other varied posts of theirs on Facebook, Instagram or Twitter). The analysis identified four (dis)identification processes: (1) the participants' selfidentification as economic, nostalgic, lifestyle and transnational migrants; (2) their other-identification by friends, by their broader social media audience and by public discourses; (3) their disidentification from their home country, from their host country and from public discourses; and (4) their identification with or disidentification from new Greek migrants and Europeans as a collective. These (dis)identification processes were found to be discursively realized by means of stance-taking, intertextuality, contextualization, and coupling.

More specifically, stance-taking enabled the participants to perform their self-presentation (see Figs. 1 and 2); to evaluate the customs of Greece and the host country (see examples 1 and 2); to express emotions shared among new Greek migrants (see example 7); to reject dominant discourses that do not recognize them as migrants (see examples 4 and 5, Fig. 8); and to disassociate themselves from certain socio-political maladies prevalent in Greece and the host country (see examples 5 and 6, Fig. 7). Stance-taking was also employed by the participants' friends and members of their broader social media audience as a resource to connect with them (see Figs. 5 and 6) as well as to value them for their contribution to the new Greek migrant collective (example 3). Intertextuality allowed the participants, on the one hand, to point to public discourses about them with a view to drawing attention to the ideologies (re)produced by these discourses (see examples 4 and 5) and, on the other hand, to ironize them (see Fig. 8). Finally, facilitated by social media affordances, the participants proceeded to the entextualization as well as the coupling of verbal and visual material. In the former case, they invested the original artefacts with new meanings related to the migrant identities they wished to construct (see Fig. 8), while in the latter they indicated their (dis)identifications via hashtags and visuals (see Figs. 2, 7, 8), which complemented their verbiage and could not be seen separately the one from the other.

The findings suggest that new Greek migrant identities are multi-faceted and hybrid, imbued with social, cultural, emotional, political, and economic dimensions. For example, the informants attach to themselves the label of the economic migrant who was forced to leave Greece because of the crisis (see Fig. 1, example 7); at the same time, they construct the identity of a lifestyle migrant who enjoys life in the host country (see Figs. 3 and 4). Moreover, they construct a complex cultural identity pertaining both to Greece and to the host country. On the one hand, they identify with Greece' customs (see example 1), yet they disidentify from Greece as a social entity, its politicians (see example 5), its welfare system (see Fig. 7), and the mentality of some of its people (see example 9). On the other hand, they appear as being adjusted to the traditions of the host country (see example 2), enjoying the good life there (see Figs. 3 and 4), but distancing themselves from certain aspects of the host society, such as criminality and racism (see example 6). Additionally, their identities are also indexed through the rejecting stances they take towards the broader public discourses on new Greek migration (see examples 4 and 5, Fig. 8). At this juncture, it should be highlighted that the (dis)identification processes through which the participants present themselves online bear resemblances to how migrants do so in offline environments (see, inter alia, De Fina, 2003; Krzyżanowski and Wodak, 2007; Benson, 2011; Karachaliou et al., 2018; Pratsinakis et al., 2020), of course with different affordances at their disposal.

So, what distinguishes this digital migrant (dis)identifications? To commence with, the projection of the participants' identities is 'polymediated' (Madianou and Miller, 2012). This means that they opt for posting on the platform that most aptly relays their feelings and intentions, as was the case of the lifestyle migrant identity on Instagram (see Figs. 3 and 4). The sharing of visuals, enabled by social media, was found to be instrumental in 
enhancing and consolidating the participants' migrant identities. By posting on Instagram photographs of their leisure time abroad (see Figs. 3 and 4), Dimitris and Chrysoula validate their migration experience of being at a particular place experiencing particular moments, while simultaneously they display cosmopolitanism. By selecting for his blog a background theme adorned with Greek symbols (see Fig. 2), Rigas invokes a Greek national identity. By embedding in her Facebook post the image of a Syrian wall writing (see Fig. 8), Antonia shows alignment with the message represented, drawing parallels with her own situation. In so doing, they also avail themselves of the affordances each platform provides, such as the hashtags on Twitter and Facebook (see \#1000yearsback in Fig. 7 and \#our_big_circus in Fig. 8), or the creation of migration-oriented blog sections (see Fig. 9), in creative and efficient ways.

Another fundamental aspect of the participants' digital (dis) identifications is that they are performed in front of an audience (see also Georgalou, 2017, p. 263). The data under scrutiny were gathered from environments of asynchronous digital communication. This asynchronicity has allowed the participants to reflect upon their posts before publishing them, that is, filter, evaluate and eventually choose which experiences, stances, and snapshots they would like to share with their audience, in juxtaposition to the ad hoc, spontaneous identities they constructed during the interview (see below). As was shown, (dis)identification is not solely a publicly performed self-actualized task, as the findings provided interesting insights into how the participants' social media audience constructs them through their comments and posts (see Figs. 5 and 6 , example 3 ).

On a methodological note, the two datasets, from social media and the interviews, complement each other in two ways. First, the participants perform their (dis)identifications using different linguistic and semiotic resources in each case (e.g. images and hashtags in social media, epistemic stance in the interviews). Second, disturbing aspects of their migration, such as their negative emotions towards dominant, public discourses (see example 5), and the construction of a tarnished image for the host country due to criminality and racism (see example 6), emerged only in the interviews, and not in their social media posts. On the one hand, this could be attributed to the trust and rapport built between the informants and myself (see Boellstorff et al., 2012, pp. 95-96), which enabled them to be more conversational and, thus, more revealing. On the other hand, it could be attributed to the fact that the interview entailed a minimal degree of pre-planning on the participants' part (with the exception of Rigas, the others were not aware in advance of the exact questions I was about to ask them), compared to the filtering and careful crafting of their social media posts for a wider audience. The substantial benefit accruing from this combination of data lies in that it provides a more holistic and nuanced picture of new Greek migration, enhancing our understanding of its complexity and diversity.

Although the current study is based on a relatively small number of new Greek migrants, settled in the UK and Germany only, the findings add to a growing body of literature on digital diasporas and can serve as a spur to future research. Focusing on new Greek migrants who reside in countries outside Europe, utilize different social media platforms and affordances (e.g. vlogging on YouTube, Instagram stories), and employ more diverse discourse mechanisms would be a natural progression of this work.

\section{Data availability}

The dataset is available from the corresponding author on reasonable request.
Received: 4 August 2020; Accepted: 8 June 2021;

Published online: 28 June 2021

\section{Notes}

1 In this paper, discourse is understood both linguistically, as language-in-use (uncountable noun: 'discourse'), and sociologically, after Foucault, as various forms of language use and construction of social reality (countable noun: 'discourses') (see Fairclough, 1992).

2 According to Bartolini et al. (2017), there is lack of reliable and comparable official data on migration patterns from Southern Europe. It is estimated, though, that since the eruption of the crisis, over 400,000 citizens have left Greece (Pratsinakis, 2019a).

3 Approximately, two out of three new Greek migrants are university graduates (Labrianidis and Pratsinakis, 2016). However, it must be noted that new Greek migration does not exclusively concern the young and the educated, since older people, people with fewer qualifications, immigrants or people from minority groups have also left Greece (Pratsinakis et al., 2019a).

4 In Halliday's (1994) Systemic Functional Grammar, language is seen as performing three functions: the ideational function (construction of a version of the world), the interpersonal function (shaping of social relationships and identities) and the textual function (organization of linguistic message into text).

5 For more details, see https://youth-in-crisis.weebly.com/.

6 With the exception of the bloggers (Dimitris, Rigas, and Chrysoula), whose real names where retained with their consent, the other two names are pseudonyms.

7 Following Silverstein (1976), Stamou (2018, p. 574) elucidates that the concept of indexicality refers to the forging of semiotic links between linguistic/visual forms and social meanings, that is to say, the process via which specific linguistic/visual features become associated with specific identities.

8 Apart from a lifestyle identity, we notice that Chrysoula simultaneously constructs the identity of a mother, both visually and verbally, through the caption 'Mom on duty' and the hashtags \#kids, \#instakids and \#momonduty. The identity of the migrant parent was not only projected by Chrysoula but by Dimitris and Rigas as well. Yet, I opted for leaving the specific identity facet outside the scope of the current study, as it deserves a paper-length treatment on its own.

9 In the original Greek utterance, 'you' is used as a second person plural pronoun.

10 The following transcription conventions are used: (.) micropause, (0.5) the time elapsed (by tenths of seconds) between the end of the utterance and the start of the next utterance, - self-repair,: sound prolongation, text stress, [] additional contextual information, ... omitted material.

11 Kostas Kazakos (born in 1935) is a veteran Greek actor and director. He has been elected twice as a member of the Greek Parliament with the Communist Party of Greece.

12 The excerpt is available here (in Greek): https://www.youtube.com/watch? $\mathrm{v}=\mathrm{A}$ hDYsMgKIE (Accessed 17 June 2021).

13 Our Big Circus, written by Iakovos Kampanellis, is a political, satirical play staged in 1973-1974, during the military junta in Greece. Due to the anti-junta messages of the play, the protagonists were arrested and imprisoned for three months.

14 Although the titles of the blog's sections and subsections are in English, the posts are written in Greek.

15 According to Theodoropoulou (2014, p. 89): “'Bouzoukia' is a synecdoche referring to the way of Greek entertainment, translated into going to music scenes, where folk music is performed by popular artists, led by the sound of the Greek instrument, called bouzouki. Even though bouzouki is also involved in rebetika, the latter nowadays are not seen as much of lower status as bouzouki popular folk music. This type of folk music is considered as lacking quality and being decadent in general, as

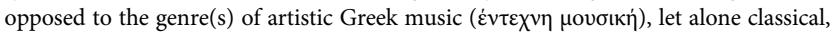
music, which are seen of higher social status".

\section{References}

Abell J, Myers G (2008) Analysing research interviews. In: Wodak R, Krzyżanowski M (eds.) Qualitative discourse analysis in the social sciences. Palgrave Macmillan, Basingstoke, pp. 145-161

Aguirre AC, Graham Davies S (2015) Imperfect strangers: picturing place, family, and migrant identity in Facebook. Discourse Context Media 7(1):3-17. https://doi.org/10.1016/j.dcm.2014.12.001

Androutsopoulos J (2008). Potentials and limitations of discourse-centred online ethnography. Language@Internet 5. https://www.languageatinternet.org/ articles/2008/1610. Accessed 16 June 2021

Androutsopoulos J (2013) Online data collection. In: Mallinson C, Childs B, Herk GV (eds.) Data collection in sociolinguistics: methods and applications. Routledge, New York, pp. 236-250

Aravossitas T, Sugiman M (2019) From brain drain to brain gain: New Greek migration to Canada and implications for the community. In: Panagiotopoulou JA, Rosen L, Kirsch C, Chatzidaki A (eds.) 'New' migration of families 
from Greece to Europe and Canada: a 'new' challenge for education? Springer VS, Wiesbaden, pp. 33-56

Bakhtin M (1981). Discourse in the novel. In: Holquist M (ed) The dialogic imagination: four essays by M.M. Bakhtin (trans: C. Emerson C, Holquist M). University of Texas Press, Austin

Bartolini L, Gropas R, Triandafyllidou A (2017) Drivers of highly skilled mobility from Southern Europe: escaping the crisis and emancipating oneself. J Ethn Migr Stud 43(4):652-673. https://doi.org/10.1080/1369183X.2016.1249048

Benson M (2011) The British in rural France: lifestyle migration and the ongoing quest for a better way of life. Manchester University Press, Manchester

Benwell B, Stokoe E (2006) Discourse and identity. Edinburgh University Press, Edinburgh

Biber D, Finegan E (1989) Styles of stance in English: lexical and grammatical marking of evidentiality and affect. Text 9(1):93-124. https://doi.org/10.1515/ text.1.1989.9.1.93

Boellstorff T, Nardi B, Pearce C, Taylor TL (2012) Ethnography and virtual worlds: a handbook of method. Princeton University Press, Princeton

Blommaert J (2005) Discourse: a critical introduction. Cambridge University Press, Cambridge

Brubaker R, Cooper F (2000) Beyond 'identity'. Theory Soc 29(1):1-47. https://doi. org/10.1023/A:1007068714468

Chafe W (1986) Evidentiality in English conversation and academic writing. In: Chafe W, Nichols J (eds.) Evidentiality: the linguistic coding of epistemology. Ablex, Norwood, pp. 261-272

De Fina A (2003) Identity in narrative: a study of immigrant discourse. John Benjamins, Amsterdam

Diminescu D (2008) The connected migrant: an epistemological manifesto. Soc Sci Inf 47(4):565-579. https://doi.org/10.1177/0539018408096447

Du Bois JW (2007) The stance triangle. In: Englebretson R (ed.) Stancetaking in discourse: subjectivity, evaluation, interaction. John Benjamins, Amsterdam, pp. $139-182$

Fairclough N (1992) Discourse and social change. Polity Press, Cambridge

Georgalou M (2017) Discourse and identity on Facebook. Bloomsbury, London

Georgalou M (2019) Place identity construction in Greek neomigrants' social media discourse. Internet Pragmat 2(1):136-161. https://doi.org/10.1075/ ip.00026.geo

Georgalou M (2020) Critical analysis of new Greek migrant discourse: Intertextuality and identities in social media [in Greek]. In: Boukala S, Stamou AG (eds.) Critical discourse analysis: (De)constructing Greek reality. Nissos, Athens

Georgalou, M (2021). Emotions and migration in social media discourse: a new Greek migrant case study. Emotion Space Soc 38. https://doi.org/10.1016/j. emospa.2020.100745

Georgalou M, Saltidou TP, Griva E (2019) Young people in crisis: constructions of brain drain in the discourse of Greek neomigrants and the media [in Greek]. Multiling Acad J Educ Soc Sci 7(1):94-113. https://doi.org/10.46886/ MAJESS/v7-i1/5942

Goffman E (1956) The presentation of self in everyday life. University of Edinburgh, Edinburgh

Groutsis D, Vassilopoulou J, Kyriakidou O, Özbilgin MF (2019). The 'new' migration for work phenomenon: the pursuit of emancipation and recognition in the context of work. Work Employ Soc. https://doi.org/10.1177/ 0950017019872651

Halliday MAK (1994) An introduction to functional grammar, 2nd edn. Arnold, London

Jaffe AM (2009) Introduction: the sociolinguistics of stance. In: Jaffe AM (ed.) Stance: sociolinguistic perspectives. Oxford University Press, Oxford, pp. $3-28$

Jones R, Chik A, Hafner CA (2015) Introduction: discourse analysis and digital practices. In: Jones R, Chik A, Hafner CA (eds.) Discourse and digital practices: doing discourse analysis in the digital age. Routledge, Abingdon, pp. $1-17$

Karachaliou R, Tsakona V, Archakis A, Ralli A (2018) Constructing the hybrid identity of the "Stranger": the case of Greek immigrants in Canada. Tertium Linguist J 3(1):127-152. https://doi.org/10.7592/Tertium2018.3.1.Tsakona

Kiesling SF (2011). Stance in context: affect, alignment and investment in the analysis of stancetaking. Paper presented at the i-Mean 2 Conference, 15 April 2012. The University of the West of England, Bristol, UK

Kristeva J (1986) Word, dialogue and novel. In: Moi T (Ed.) The Kristeva reader. Blackwell, Oxford, pp. 35-61

Krzyżanowski M, Wodak R (2007) Multiple identities, migration and belonging: voices of migrants. In: Caldas-Coulthard C-R, Iedema R (eds.) Identity trouble: critical discourse and contested identities. Palgrave Macmillan, Basingstoke, pp. 95-119

Labrianidis L, Pratsinakis M (2016). Greece's new emigration at times of crisis. GreeSE: Hellenic Observatory Papers on Greece and Southeast Europe, paper 99, Hellenic Observatory, LSE. http://eprints.lse.ac.uk/66811/1/GreeSENo.99.pdf. Accessed 16 June 2021
Leaver T, Highfield T, Abidin C (2020) Instagram: visual social media cultures. Polity Press, Cambridge

Leppänen S, Kytölä S, Jousmäki H, Peuronen S, Westinen E (2014) Entextualization and resemiotization as resources for identification in social media. In: Seargeant P, Tagg C (eds.) The Language of social media: identity and community on the internet. Palgrave Macmillan, Basingstoke, pp. $112-136$

Leppänen S, Westinen E, Kytölä S (eds.) (2017) Social media discourse, (dis) identifications and diversities. Routledge, New York

Leppänen S, Kytölä S, Westinen E, Peuronen S (2017) Introduction: Social media discourse, (dis)identifications and diversities. In: Leppänen S, Westinen $\mathrm{E}$ Kytölä S (eds.) Social media discourse, (dis)identifications and diversities. Routledge, New York, pp. 1-35

Leurs K (2015) Digital passages: migrant youth 2.0. diaspora, gender and youth cultural intersections. Amsterdam University Press, Amsterdam

Leurs K, Prabhakar M (2018) Doing digital migration studies: methodological considerations for an emerging research focus. In: Zapata-Barrero R, Yalaz E (eds.) Qualitative research in European migration studies. IMISCOE Research Series. Springer, Cham, pp. 247-266

Madianou M, Miller D (2012) Migration and new media: transnational families and polymedia. Routledge, London

Martin JR (2000) Beyond exchange: appraisal systems in English. In: Hunston S, Thompson G (eds.) Evaluation in text: authorial stance and the construction of discourse. Oxford University Press, Oxford, pp. 142-175

Myers G (2010) The discourse of blogs and wikis. Continuum, London

New Diaspora (2016). The number of Greeks who moved abroad during the crisis. http://www.newdiaspora.com/the-number-of-greeks-who-moved-abroadduring-the-crisis/. Accessed 17 June 2021

Page R (2012) Stories and social media: Identities and interaction. Routledge, London

Panagiotopoulou JA, Rosen L, Kirsch C, Chatzidaki A (eds.) (2019) 'New' migration of families from Greece to Europe and Canada: a 'new' challenge for education? Springer VS, Wiesbaden

Pratsinakis M (2019a) Family-related migration and the crisis-driven outflow from Greece. In: Panagiotopoulou JA, Rosen L, Kirsch C, Chatzidaki A (eds.) 'New' migration of families from Greece to Europe and Canada: a 'new' challenge for education? Springer VS, Wiesbaden, pp. 11-32

Pratsinakis M (2019b). Social and discursive constraints and the decision to leave: emigration from Greece at times of crisis. SEESOX Diaspora Working Paper Series. Paper No. 7. http://seesoxdiaspora.org/assets/site/papers/ Pratsinakis_WP.pdf. Accessed 17 June 2021

Pratsinakis M, Hatziprokopiou P, Grammatikas D, Labrianidis L (2017) Crisis and the resurgence of emigration from Greece: Trends, representations, and the multiplicity of migrant trajectories. In: Glorius B, Domínguez-Mujica J (eds.) European mobility in times of crisis: the new context of European South-North migration. Transcript Verlag, Bielefeld, pp. 75-102

Pratsinakis M, King R, Himmelstine CL, Mazzilli C (2020) "A crisis-driven migration? Aspirations and experiences of the post-2008 South European migrants in London". Int Migr 58(1):15-30. https://doi.org/10.1111/ imig. 12583

Seargeant P, Tagg C (eds.) (2014) The language of social media: identity and community on the internet. Palgrave Macmillan, Basingstoke

Seargeant P, Tagg C (2014) Introduction: the language of social media. In: Seargeant $\mathrm{P}$, Tagg $\mathrm{C}$ (eds.) The language of social media: identity and community on the internet. Palgrave Macmillan, Basingstoke, pp. 1-19

Silverstein M (1976) Shifters, linguistic categories and cultural description. In: Basso KH, Selby HA (eds.) Meaning in anthropology. University of New Mexico Press, Albuquerque, pp. 284-306

Siouti I (2019) New migrations from Greece to Germany in times of the financial crisis: Biographical research perspectives. In: Panagiotopoulou JA, Rosen L, Kirsch C, Chatzidaki A (eds.) 'New' migration of families from Greece to Europe and Canada: a 'new' challenge for education? Springer VS, Wiesbaden, pp. 57-72

Stæhr A (2015) Normativity as a social resource in social media practices. In: Madsen LM, Karrebæk MS, Møller JS (eds.) Everyday languaging: collaborative research on the language use of children and youth. Mouton De Gruyter, Berlin, pp. 71-94

Stamou AG (2018) Studying the interactional construction of identities in Critical Discourse Studies: a proposed analytical framework. Discourse Soc 29 (5):568-589. https://doi.org/10.1177/0957926518770262

Tagg C (2015) Exploring digital communication: language in action. Routledge, Abingdon

Tannen D (2007) Talking voices: repetition, dialogue, and imagery in conversational discourse, 2nd edn. Cambridge University Press, Cambridge

Theodoropoulou I (2014) Sociolinguistics of style and social class in contemporary Athens. John Benjamins, Amsterdam/Philadelphia

Vertovec S (2004) Migrant transnationalism and modes of transformation. Int Migr Rev 38(3):970-1001. https://doi.org/10.1111/j.1747-7379.2004.tb00226.x 
Zappavigna M (2012) Discourse of Twitter: how we use language to create affiliation on the web. Bloomsbury, London

Zappavigna M (2018) Searchable talk: Hashtags and social media metadiscourse. Bloomsbury, London

Zappavigna M, Zhao S (2020) Selfies and recontextualisation: still life self-imaging in social media. In: Miles M, Welch E (eds.) Photography and its publics. Bloomsbury, London, pp. 205-227

Zhao S (2011). Learning through multimedia interaction: the construal of primary social science knowledge in web-based digital learning materials. PhD thesis, Department of Linguistics, University of Sydney, Sydney

\section{Acknowledgements}

I wish to thank Naomi Wells, Francielle Carpenedo, Saskia Huc-Hepher, and Jane Winters for their interest in my research as well as Anastasia Stamou for her valuable suggestions on earlier versions of this paper. I am very grateful to Dimitris, Thalia, Antonia, Chrysoula, and Rigas for their participation in the study.

\section{Competing interests}

The author declares no competing interests.

\section{Additional information}

Correspondence and requests for materials should be addressed to M.G.

Reprints and permission information is available at http://www.nature.com/reprints

Publisher's note Springer Nature remains neutral with regard to jurisdictional claims in published maps and institutional affiliations.

(c) (i) Open Access This article is licensed under a Creative Commons Attribution 4.0 International License, which permits use, sharing, adaptation, distribution and reproduction in any medium or format, as long as you give appropriate credit to the original author(s) and the source, provide a link to the Creative Commons license, and indicate if changes were made. The images or other third party material in this article are included in the article's Creative Commons license, unless indicated otherwise in a credit line to the material. If material is not included in the article's Creative Commons license and your intended use is not permitted by statutory regulation or exceeds the permitted use, you will need to obtain permission directly from the copyright holder. To view a copy of this license, visit http://creativecommons.org/ licenses/by/4.0/.

(C) The Author(s) 2021 